\title{
Women in Mount Tengger Folklores: Their Presence, Position and Environmental Knowledge of Disaster Mitigation
}

\author{
Sony Sukmawan'; Lestari Setyowati ${ }^{2}$ \\ ${ }^{1}$ Universitas Brawijaya, Indonesia \\ ${ }^{2}$ Universitas Negeri Malang, Indonesia \\ Corresponding Author: sony_sukmawan@ub.ac.id
}

\begin{abstract}
Tenggerese people in East Java are one of Indonesia's ethnic communities endowed with a unique folklore. This ethnographic research aimed to find out 1) how women are presented in Mount Tengger folklore; 2) the position of women in Tengger folkore; and 3) Tenggerese women's environmental knowledge in relation to nature and disaster mitigation. Data analysis used multi perspective dimensions by employing theories of ecofeminism, ecocriticism, and folkloristic views. Human instruments, observations, interviews, and documentation were used in this study. The findings revealed that 1) women are presented both in Tengger folktales and oral poetry (spells), and are characterized as being mentally strong, respected, and having the proclivity to protect the environment. 2) In Tenggerese folklore, women enjoy equal position with men. The equality between men and women has become a social value and practice within Tenggerese traditions. Women work side-by-side with men in their domestic lives and beyond. 3) Tenggerese women have extensive environmental knowledge, in both the physical and psychological sense. They have in-depth and detailed knowledge of the vitality of nature for human living.
\end{abstract}

Keywords: environmental knowledge; folklore; Tengger; women

\section{INTRODUCTION}

Folklores, especially the geo-cultural or geo-mythological oral literature, should be prioritized and in literary studies due to the rich ecological values that they contain. Those values not only give the community useful lessons on potential natural disasters, but also give practical advice to people on they ways to mitigate those calamities so that they can live in harmony with the environment. Sukmawan (2015) reveals that Indonesian folktales contain local wisdoms that can serve as guidance for disaster mitigation that can help lessen the risks. Therefore, efforts to extract useful lessons from the local wisdom through a comprehensive review of oral tradition as part of cultural disaster mitigation efforts are urgent, especially in disaster-prone areas.
Located in East Java, Mount Tengger is one of many disaster-prone areas in Indonesia. The area is under constant threat from the volcanic eruption of Mount Bromo. Despite the imminent danger, Mount Bromo is regarded by Tenggerese people as a beautiful divine gift. Bromo is perceived as a living mountain, forever guarded by the ancestors. The intimate relationship between Tenggerese people, especially the women, and Mount Bromo serves as the doorway for these women to build their recursive and comprehensive understanding of nature. Their understanding of natural system is passed down verbally from generation to generation and such an understanding defies scientific explanation (Mitchell, Setiawan, \& Rahmi, 2000). Tenggerese folklores that are 
born from the community's oral culture and find their expressions in traditional dances, local customs and people's behavior deliver people's reflection of nature.

As a medium of collective reflection on the natural system, folklore is laden with environmental wisdom (Sukmawan, 2018). This implies the close connection between humans, nature, oral literature, and local knowledge (Butterfield, 1993). Studies of oral literature, as part of folklore, have been conducted by numerous researchers. The first is a study by Jensen (2009). She compares the Lithuanian and Tasmanian forest poetry written in the 19th century and how they relate to the present-day conservation movements. The findings indicate the existence of folklore and mythology in The Forest of Anykščiai poem. She concludes that the poem contains Lithuanian mythology which describes nature as a complex ecosystem, whereas the Tasmanian poetry written in the colonial era describes nature as aesthetic, albeit simplified image. She further states that for Lithuanian and Tasmanian people, the forest becomes a cultural landscape that strengthens their sense of belonging and national identity which then serve as the basis of their moral responsibility for the conservation movement.

In Indonesia, studies on local wisdom in folklore, oral literature, oral tradition, and non-verbal traditions are numerous. Among those who researched this topic are Suyitno (2008) who investigated the expression of Oseng ethnic culture in Banyuwangi as expressed in their songs; Majeri Mangunjaya \& Elizabeth McKay (2012) and Mangunjaya (2011) who investigated the Contribution of Islam in Natural Conservation; and Triyoga (2010) who investigated the perceptions and beliefs of Javanese living around Mount Merapi. Another study was conducted by Riley (2010) who investigated the Villager's folklore in Lore Lindu National Park, Sulawesi, Indonesia. His study shows that villagers of Lore Lindu believe in the biological, ecological, and cultural interconnect-ion between apes and humans which finds its expressions in the local taboo: humans must not harm the monkeys. The latest studies were carried out by Leoni \& Indrayatti (2017) and Sukmawan (2018). Leoni \& Indrayatti (2017) investigated the folklores in Kepulauan Riau and found out that the local folklore contains local wisdom that people put into practice every day, in traditional ceremonies, social systems, and relationships. Whereas Sukmawan's (2018) study reveals that oral literature of people living in the slopes of Mount Arjuna contains apocalyptic ideas. The result of the latter study shows that the apocalyptic ideas of oral literature on the slopes of Mount Arjuna slope are reflected in the practice of assigning names to the villages, ancient sites and natural sacred sites, and the naming of the baureksa (local guardian spirits) in the spells, which draw the inspiration from the fragments, quotations, or partial stories of wayang, suluk, and ancient scriptures.

Tenggerese people and their folklores are of special interest to many researchers. Firstly, Setiawan (2008) investigated Tenggerese women's roles in their domestic, social lives, and in traditional rites. His research finding shows that Tenggerese women play some crucial roles in taking care of the families, promoting their families' welfare, educating their children, participating in social life, and taking part in traditional rites. Secondly, Mariati (2013) investigated the magic cultural values of Tenggerese culture. The findings of her study shows that cultural values of magic and spells are the representation of their prayer and the mantras, recited or chanted during the prayers, or other religious subculture, performed in the religious ceremonies, are owned by a shaman (dukun pandhita). The people of Tengger regard dukun as the most important figure in their community. Further, Sutarto (2003) describes how Tenggerese oral tradition plays a crucial role in preserving local tradition. The finding shows that Tenggerese oral traditions become the main pillar of the local culture through their folklores (the legend of Kasada, Karo, and mantra). Thirdly, Negara (2018) investigated how Tenggerese people develop and maintain their shame culture to prevent conflict. The research finding reveals that Tenggerese people maintain their shame culture through religious education, family education, admonitions given by the elderly to the young, and social suggestions by instilling values they draw from their folklores. Fourthly, Sukmawan \& Febriani (2018) investigated Tenggerese women's perception of themselves, their relation to traditional rites, and their dynamic life. The result reveals that Tenggerese women view themselves as hard workers and the ones who take responsibility for the domestic life. Moreover, they also maintain the family's financial stability while taking care of the communal life.

Several conclusions can be drawn from the previous studies. First, in general, oral literature as part of folklore has not been adequately investigated. The previous studies put more emphasis on the anthropological view. At this level, the religious-cultural context takes precedence over the textual and literal aspects of folklore (oral literature). Secondly, some of the previously mentioned research findings also seek to explore local wisdom (ecological wisdom) which is contained in the beliefs of the community. So far, however, no studies have been carried to explain environmental wisdom 
in female-oriented folklores. In other words, women's environmental wisdom has not been fully explored in studies on local folklore. The issues indicate that the representation of environmental wisdom values has not been adequately researched. Therefore, despite the abundant research on folklore in Indonesia, little is done to investigate the relationship between women and folklore. In sum, oral literature -- not written literature or documented oral literature -- as part of the oral tradition, has never been treated as the focal point of many studies. Thus, a systematic and in-depth study of the values of Tenggerese women's wisdom in Tenggerese folklore for the maintenance, preservation, and recovery of natural resources and disaster mitigation is worth doing. In the present study, the research questions are formulated as follows. 1) How are women presented in Tengger Mountains folklores?

2) What is women's position in Tenggerese folklores? and 3) How does Tenggerese women's environmental wisdom shape their conservative or mitigative behavior?

\section{METHOD}

This qualitative study used an inter-disciplinary approach. Such approach helps solve problems from a different point of view by using relevant cognates in an integrated manner (Sudikan, 2015). Ecofeminism theory and ecocritical approach were used in combination with cultural approaches, environmental ethics, and folkloristic approach.

The subjects of the study were Tenggerese people who still adhere to their customs and traditions. The informants of this study were the shamans (dukun Pandita) and their wives who are highly respected and honored by their community thanks to their extensive knowledge about their folklores (customs, traditions, and rituals). Tenggerese villages are located around Mount Tengger Mountains in East Java. Some of the said villages are scattered in Malang, Pasuruan, Lumajang, and Probolinggo districts in East Java, and the inhabitants are predominantly Hindu and they still honor their ancestral customs (Smith-Hefner, 1990). Data collection took approximately two years because respondents live in far-flung areas.

For data collection the researchers used a qualitative approach focusing on ethnographic design (Creswell, 2007) to express the cultural significance and meaning of Tenggerese people's way of life, which finds its expression in almost anything, including through their folklores (Endraswara, 2010). In a qualitative study, the human instrument becomes the most important tool in the collection and interpretation of data (Cresswell, 2003). However, other instruments were also used, namely unstructured interview, observation, and docu-mentation. The unstructured interview was deemed appropriate for the qualitative research as this instrument serves the main purpose of discovering the essential bits of data (Wilson, 2014) and to provide more profound explanations of the reasons, emotions, feelings, actions, and motivations of the subjects under study from their points of view (Compton, 2005). The researchers performed regular conversation in an intimate and friendly manner with the subjects of the study by asking some ethnographic questions within the conversation to learn how the members of a particular community see the world from their unique perspectives (Spradley \& McCurdy, 2012).

The researchers also conducted observations to collect the data. As stated by Cresswell (2003) observational data is very crucial in ethnography study. Thus, the research data is in the form of folkloristic expressions embodied in expressions, speeches, or oral expressions, actions/movements, or symbolic behaviors that carry the value of women's environmental wisdom. To assist the researchers in analyzing the data, a simple coding system was used. The data was analyzed qualitatively since most of the data were non-numerical ones. The data analysis follows Miles \& Huberman's (1994) model which begins with data reduction, data display, conclusion, and verification. However, as stated by Rijali (2019), in a qualitative study, data analysis is not in a linear process as it is integrated to the data collection, so the researchers can go back and forth to the data collected during the data analysis.

\section{FINDING}

\section{Women's Presence in Tenggerese Folklore}

Women are presented both in Tenggerese folktales and oral poetry. Many of Javanese myths and tales depict mentally strong, independent, protective, powerful female characters (Dewi Nawangwulan in the tale of Jaka Tarub, Dewi Sekartaji, in the tale of Ande-ande Lumut, Nyai Gadungmelati in a myth about Mount Merapi). In the legend of Tengger, the figure of women imbued with the above characteristics is Roro Anteng. Roro Anteng in many versions is portrayed as a formidable, strong, hardworking, and intelligent woman. At least, in Sutarto's research (2017), the records of the intelligence of the main character Dewi Rara Anteng or Nini Umah or Nini Tengger as a wirawati is evident in Kasada legend of 
Tengger Lumajang. In this version, the wirawati, Rara Anteng, plays more roles than Jaka Seger, her male counterpart. Her dominant role is highlighted when Rara Anteng concocts a deception to thwart the attempts of Bima Sakti who wants to marry her (Sutarto, 2017) Tenggerese women share the belief that Roro Anteng also has these characteristics: she is tough but altruistic. It is no wonder that the character of Roro Anteng becomes the role model among Tenggerese women because she is highly respected by the people there. Tenggerese women's proclivity to emulate Roro Anteng's strong character is widely known by people living in Tengger and beyond.

Tenggerese women are not the same as any other women. Tenggerese women are strong, polite, diligent, and courageous. We rarely misbehave. The spirit of cooperation among us is also very strong. For example, one week before a wedding ceremony is held, we start to help the host (Informant 1/F/Hariati/39).

Tenggerese folktale tells the presence of female figures possessing various characteristics that are displayed either explicitly or implicitly. The tale of the village of Mororejo brings out the figure of a firm and patriotic woman in the mother of King Brawijaya. Meanwhile, the figure of women who are willing to sacrifice for others is shown in the legend of Sekam Ndawa Village.

Women are also presented in the oral poetry (mantras) of the Tengger community. These mantras are recited by the spiritual leaders during religious ceremonies, when locals build a house or celebrate the arrival of new family members, in wedding ceremonies, funerals, and village salvations. When samans chant the mantras, the spiritual presence of women can be seen in the figures of danyang (local term for guardian spirits) who are believed to guard many places in Tengger. Tenggerese women can be categorized into three types, each of which emulate the traits of moncopat (the guardian spirit of the cardinal directions) the local guardian spirit, and village guardian spirit. The position of spirit moncopat in the spell of pamenyanan is under Nini Nyokro Buono Kaping and Sewelas. The female local guardian spirits who reside in the villages of Tengger region are also mentioned in several magical chants. In a chant called Ngaturen Sajen Tamping, the spirit is named Nini Towok who is in charge of danyang umah (guardian spirit of the house), Nini Sorosoti, who is known as danyang pawon (the guardian spirit of the kitchen), Nini Kolo Kancing, who is lolcally known as danyang lawang (the guardian spirit of the door), and Nini Kolo Kenjer, the guardian spirit of the road, Nini Soro Soti, the guardian spirit of fire; Nini Kolo Kancing, who is also known as danyang lawang (the guardian spirit of the door); Nini Kolo Jenger, danyang jogan (the guardian spirit of the ground); and Nini Kolo Kenjer, who is known as the danyang dalan (the guardian spirit of the street). These guardian spirits safeguard the space inside and outside the house.

The women of Tenggerese villages include Nini Sundari (the guardian spirit of Argosari village), Nyai Juminah (the guardian spirit of Padakaya village), Mbah Srintil (the guardian spirit of Kaliteja village), Mbah Mauni (the guardian spirit of Mororejo village), Nini Purwosari, Nini Mergosari, and Nini Sumber-sari (whose names are mentioned in Pamenyanan magical chants). In a nutshell, the presence of those guardian spirits is manifested the magical chants that carry their names.

\section{Women's Position in Tenggerese Folklore}

In Tengger, women and men are equals. Equality between Tenggerese men and women has become a value which is widely practiced in the local customs. In the oral tradition, important lessons on equality are presented in the story of Rara Anteng and Jaka Seger (Setiawan, 2008: 146). The male and female personae of this story help each other in their domestic life and beyond. Rara Anteng is not only responsible for handling the work at home; she also helps Jaka Seger till the land. The epic struggle of two mythological creatures in the legend of Bromo mountain has profoundly affected the socio-cultural construction of men and women, that in both domestic and community life they share the same position. The spirit of gender equality serves as the foundation of Tenggerese women's strategic roles in their communities(Setiawan, 2008: 139-140).

The spirit of equality between men and women in finds its roots in several Tengger folklores, like the Legend of Karo, and is visually expressed in traditional dances called Sodoran and Ujung. In the legend of Karo legend, men and women are personified in Setia and Setuhu, servants of Aji Saka. Setia symbolizes men and Setuhu is the symbol of women. These characters carry out different assignments. In this tale, Setia has to escort his master Aji Saka on an epic journey to the Kingdom of Medang kamulan to meet King Dewata Cengkar.

Meanwhile, Setuhu stays in the place to look after Sarutama heirloom. Both Setia and Setuhu are strongly committed to their duties even though their lives are at stake. This narrative bears the symbol of men and women's obligation to share equal roles while maintaining loyalty and responsibility. Furthermore, Setia and Setuhu symbolize the Sarutama heirloom. This heirloom is also 
considered a symbol of the constituent elements of life.

Ujung and Sodoran dances are always staged to mark the Yad Karo ritual. Tenggerese people who faithfully preserve their tradition explain that the ritual is intended to protect local men and women (symbolized by Setia and Setuhu). This ritual also symbolizes men and women's sacral duties to carry and bear the seed of life and fertility (Sutarto, 2008). The Yad Karo ceremony, which coincides with the full moon of Karo (15th of Karo) is one of the quintessential Tenggerese festivities, and it also symbolizes paran dumadi (the origin of human existence).

Karo symbolises the concept of paran dumadi (the origin of human existence) and this ritual has its roots in the legend of Aji Saka and his punakawan (servants) named Setia (literally meaning the loyal or faithful) and Setuhu (keeper of promises or covenants). These characters are the symbols of men and women (Informant 2/M/Eko Warnoto/44)

The origin of human life is portrayed in the Legend of Karo, especially through the figure of Aji Saka and his two servants. Ujung-ujungan dance is laden with the symbol of the faithful servants Setia and Setuhu. The dance symbolizes the battle and unification of the two lifeforming elements. Technically, Ujung dance is performed by two dancers, each carrying a tool (property) made of rattan. Rattan symbolizes the heirloom (Sarutama) symbolizes the two life-forming elements. The dancers take turns in flailing the rattan sticks and striking each other with these sticks. The dancers do not strike each other simultaneously: when one strikes, the other receives the blow. Every single blow of the rattan stick symbolizes a gift of life that they call 'nutfah'. Accepting the blow is the metaphor for their willingness to receive and plant the seed of life. Similarly, Sodoran dance is laden with philosophical values. Sodor or Sodoran is a sacral dance that is performed at the height of Karo festivity. This dance is performed by four men (or, alternatively by six men and women). Sodoran dance visually narrates the unification of man and woman: their first encounter, the courtship, romance, and nuptials.

\section{Tenggerese Women's Environmental Knowledge}

Tenggerese women have profound and extensive knowledge of the environment in the physical and psychological sense. They have in-depth and detailed knowledge about the vitality of nature for human living. They respect nature and the place they live in. As a result, they take care of nature as a part of their lives. The way these people utilize and manage water best exemplifies this wisdom. To the women of Tengger women, water is not only perceived as a natural resource that is needed for daily and domestic. They see water as a living entity; in addition to sustaining life, water also needs nurturing. They see it necessary to provide water with offerings as a way of appeasing the guardian spirits who guarantee its adequacy and sustainability. Tenggerese women's way of regarding and treating water as a living element determines the sustainability of the ecosystem because such understanding manifests itself in the way those people respect not only water but also everything that surrounds them like the forests, hills, the ground, the trees, plants, and animals who inhabit the ecosystem

Tenggerese women prepare offerings for water because they believe that water has a guardian spirit (Danyang) that controls it. Offerings for water are called tamping. These offerings are meant to satisfy the demands of the said Danyang so that they will not interfere with human life. Tamping is a small offering placed in a special place called padanyangan where the danyang is believed to dwell and reign. The dish consists of flowers like kenikir, tanlayu, and putihan leaves (eucalyptus leaves), and a piece of wheat cake (Sutarto, 2008: 246). When human life is not disturbed by the invisible spirits and when they regularly satiate the demands of the supernatural beings around them, they live side by side in harmonious coexistence. This creates a harmonious relationship between all elements of life. Thus, tamping is a symbolic device to build a harmonious life.

Tenggerese women's physical, spatial and mystical understanding of water constitutes a form of environmental knowledge. The naming of the springs, the understanding of the location of its existence, and the way they treat these natural resources seems very simple and plain. And yet, such simple understanding serves as the basis and controls their transcendental behavior. Human's humility and modest behavior is evident in their utmost respect to water as a living entity that deserves to be respected and protected. Tamping is an offering which is intended to accompany (limit, cover, protect) the life of water and its danyang, to accompany human life, to help forge the good harmonious and mutually rewarding relationship between human and the danyang. When some inconsistency occurs, Tenggerese women will make efforts to rectify the situation in rituals called the slametan in which generous offerings are made for the guarding spirits. Slametan rituals and the offerings are part of the traditional knowledge system for disaster mitigation and natural conservation. It can be said that 
tamping is an instrument for natural conservation deep down inside it serves as a religious expression and human's desire to create a harmonious life. The offering's full ingredients (local flowers such as kenikir, tanlayu, and putihan leaves), implicitly carries the ecological message to preserve several endemic plants they use in the rituals.

\section{DISCUSSION}

In a study of Merapi and its people, Triyoga (2010) sums up the manifestations of ecological wisdom in a series of offerings and ritual or salvation ceremonies. People living on the slopes of mount Merapi perform slametan to give alms of the ancestral spirits and those inhabiting the mountain. Tenggerese people perform the slametan rituals for the very same reasons. The belief in the existence of ancestral spirits that guard the village is shared by Tenggerese villagers and this faith is passed down from one generation to another Suseno (1993) reveals that Tenggerese villagers' belief in ancestral and guardian spirits is shaped by their belief in afterlife; following death, the human souls will remain close to their village to take care of the living. Such conviction is confirmed by the common belief among the Javanese people that from the very beginning of time the island of Java was inhabited by supernatural creatures. The supernatural creatures have their king or queen. The ancient chant of Suluk Dhanghyangan describes several Javanese world supernatural leaders like Ki Wenangtaji who reigned in Jepara, Ni Daruni, the sovereign of Trenggalek, Ki Tlekah Ngawang-Ngawang who ruled on mount Gunung Agung, Ni Rara Dhenok the ruler in Demak, Ki Jalela Ardi on Mount Sumbing, Ki Krama Ardi on Mount Merbabu, and many others (Hadisutrisno, 2009).

In the case of Tengger, the naming of the ruler of the universe, and spirits who guard the area of Tengger, the villages and the household premises is of utmost importance. The names and titles are a tribute to the ancestors of Tenggerese people. These characters have an important position in the locals' religious life and social life. The respect for the ancestors characterizes and bears evidence to Javanese people's dependence on the spirit (Endraswara, 2010:81). The presence of supernatural world is evident through the invisible forces. The typical Tenggerese woman perceives the universe as a place where her well-being depends on whether she can adapt herself to those spiritual powers. To appease the spirits, Tenggerese women regularly give offerings and host slametan so that so they can be spared from harms caused by the spirits and can maintain harmony with the cosmos. Cosmic harmony, then, is the ultimate aim of all these customary rites, attitudes, and beliefs learned and practiced by Tenggerese women. The variety of slametan along with the various symbols of offerings, the mentioning of ancestral spirits and their dwelling places, as well as the various naming of village danyang in Tengger local narratives, are a protective mechanism aimed at guarding the cosmos.

The sanctification of the psychic presence of baureksa (spirits who guard certain places) by Tenggerese women in the context of Tenggerese rite system is the key to Tengger area's natural conservation. The sacredness of the danyang not only affects the places they inhibit; their presence and sovereignty extend to the surrounding areas where they guard the beasts and the vegetation that people grow (Durkheim, 2001). For Tenggerese women, the universe of Tengger that psychologically presents itself in the form of sacred danyang lies between the 〈biological nature〉 (mountains, the land, the sky, the animals and plants) and the 'mind'. The psychic realms are experienced by Tenggerese in their imaginations. From the perspective of environmental ethics, their awareness of the natural intrinsic values serves as the basis of respect for nature as a part of the ecology. Recognition of the intrinsic values of nature implies the recognition of the inherent value that nature deserves to be respected. Nature earns respect not only because human life depends on it, but first because of the ontological reality that man is a part of nature. Javanese people see reality as a holistic unity. Furthermore, within the framework of the cosmocentric-spiritual Eastern outlook, man and nature are unity in harmony (Saryono, 2008). Even though slametan is imbued with social nuances, prayers for salvation chanted in the rituals extend beyond that social dimension.

Values of harmony between man and nature are not only indicated in the slametan rite along with the mantra as the most important part of the whole ritual, but they are also visible in the expression of the narratives of folklores. Tenggerese folklores are full of environmental themes. These themes make up the ethical orientation of their folklore. As a 'text,' Tenggerese folklore has a distinctive characteristic. This peculiarity is seen in the cosmic-spiritual breath born out of harmonious blending of Tenggerese spirituality and Hindu-Buddhist mysticism. This cosmos-centered spiritual breath serves as the source of the values of environmental wisdom in Tenggerese oral tradition (Sukmawan, 2015).

In the realm of education, the synergy of environmental conservation and the preservation of tradition can be created through the introduction of (oral) literary texts which deliver environmental wisdom. 
The wisdom of the environment, as an important part of indigenous knowledge of Tenggerese society, is stored in the collective memory of the people and manifests itself in their daily activities. This knowledge is expressed in stories, songs, folklore, proverbs, dances, myths, cultural values, beliefs, rituals, and social life. Environmental wisdom, as part of indigenous knowledge, is communicated orally, with specific examples, and through local culture. This form of communication and cultural habit organization is essential for locallevel decision-making processes and the preservation, development, and dissemination of this knowledge (Semali, \& Kincheloe, 1999). In addition to customary organizations, educational can potentially help preserve, develop, and even disseminate or spread the values of environmental wisdom.

The value of environmental wisdom and environmental awareness are included in one of the values of character education which has become a mainstream in Indonesian education. Character education has become an educational movement that nurtures students' social, emotional, and ethical developments. Character education marks the collective effort to teach children how to make wise decisions and practice them in their daily lives so that they can make a positive contribution to the environment (Kesuma, Triatna, \& Permana, 2013). Among the 18 characters to be taught to Indonesian learners is taking care the environment (Center of Curriculum, Ministry of National Education, 2011). Taking care of the environmental is described as attitudes and actions aimed at preventing the damage to the surrounding environment and making efforts to repair the damaged ecosystem (Listyarti, 2014).

In the case of Tenggerese women under this study, it is apparent that their attitudes and life principles are meant to (i) respect nature, as indicated in the mention of cosmic spirits in the recitation of mantra; (ii) maintain cosmic solidarity, as reflected in of various slametan rituals; (iii) have a moral responsibility for nature, as reflected in one of the goals of slametan., to restore natural equilibrium; and (iv) to hold up the principle of not to causing harm to nature, to lead a simple life and maintain harmony with nature, as is reflected in the utilization of natural elements and ingredients for the offerings. These are the realities of the environmental wisdom of Tenggerese women. The consensus of ecofeminism in liberal view is the improvement of normative devices for women to overcome the social stigma of their biological characteristics and join men in environmental conservation projects (Merchant, 1990). They regard working hand in hand with men (husbands) as something positive. These women have managed to overcome their otherwise stigmatized biological characteristics by joining men (husbands) in managing and conserving nature. Implementing customary obligations jointly with men has become a norm among Tenggerese women as a manifestation of maintaining of justice (Sutarto, 2003:40). In solving problems, these women always prioritize the importance of harmony, make prior agreements with their husband and avoid violence. The number of customary rituals they perform each year does not necessarily make Tenggerese women feel burdened and confined by male domination. They do not see it necessary to talk about radical feministic ideas of women's liberation, or the idea of socialist feminism about the dominance of structures because their willingness to preserve and cherish their ancestral heritage overrides those ideas This attitude enables Tenggerese women to live their daily lives peacefully. Maintaining ethics as one of the spiritual philosophies of radical eco-feminism has long been practiced in their lives and such tradition has been preserved for generations. For Tenggerese women, nature is spiritual and personal.

\section{CONCLUSION}

Several conclusions can be drawn from the findings of this study. Firstly, Tenggerese folklore presents women as respected figures, both in folktales and oral poetry. Women are portrayed in the folklore as characters having noble personality: mentally strong, respectable, having the innate proclivity to guard the nature.

These characteristics reflect the traits of the guardian spirits (danyang, pepunden, or baureksa) who keep watch of the regions' time and places. Tenggerese women believe that the presence of supernatural powers (spirits) not only influences their social lives but also has a preservatory effect on nature. Secondly, the folklore also contains the depiction of the equality between men and women, where they share the same domestic and social responsibilities, as shown in their traditional dances (Sodoran and Ujung), their folktales (The Legend of Karo, the story of Roro Anteng and Jaka Seger), and religious rituals. Tenggerese women work side-by-side with men (their husbands) to manage and conserve nature through job divisions during the observance of slametan and customary rituals. These special mechanisms of rituals and offerings are believed to help people to maintain and restore their harmonious relationships with nature. Thirdly, Tenggerese women have in-depth environmental knowledge, as is reflected in their folklore and offerings, the latter of which are known as tamping. As part of 
their moral responsibility for nature, Tenggerese women hold slametan rituals that metaphorically serve to restore the cosmic balance. Slametan thus becomes the heart of natural conservation. The significance of slametan rituals in anticipating or mitigating disasters is not practical or technical, but rather symbolic.

The ecological messages that can be drawn from women in Tenggerese folklore are (1) having a respect for nature is the starting point for attempts to save the environment, whereas disrespect marks the beginning of environmental destruction; (2) cosmic solidarity assures the harmonious relationship between Tenggerese woman and nature ; (3) natural disasters are addressed as a form of natural imbalance triggered by the wrong behavior of Tenggerese people. Considering the wealth of environmental teachings contained in Tenggerese folklore, its relevance to character education, along with the importance of institutionalizing indigenous knowledge in local education policy, it is necessary to enshrine Tenggerese folklore in the local content curriculum. This will not only preserve Tenggerese cultural heritage but also save future generations from "cultural amnesia."

Some recommendations can be made for local education policymakers and future researchers. Firstly, since the values of environmental wisdom contained in Tenggerese folklore are highly relevant to character education, it would be appropriate to make it the centerpiece of the of local content because so far Tenggerese cultural wealth has been given little attention in the local educational policy. The inclusion of Tenggerese folklore in the local content curriculum may enrich future generations' knowledge of their cultural values and wisdom, as nowadays many young Tenggerese people are becoming "aliens" to their own culture. After all, it is the younger generation that bears the responsibility to protect, preserve, and maintain their community's cultural identity. Secondly, since this study focuses mainly on verbal folklore (mantra, songs, legend, myths) and partly verbal folklore (dance), future researchers are advised to explore other types of folklore, with an emphasis on the material folklores (house, traditional costumes, traditional food, and beverages). These folklores, sadly, have not been explored much.

\section{REFERENCES}

Butterfield, D. (1993). Toccata and Fugue: The Hegemony of the Eye/I and the Wisdom of the Ear. The Trumpeter, 10(3), 106-111.

Center of Curriculum National Education Ministry. (2011). Pedoman Pelaksanaan Pendidikan Karakter:
Berdasarkan Pengalaman di Satuan Pendidikan Rintisan. Jakarta: Pusat Kurikulum Balitbang Kemdiknas.

Compton, S. (2005). Qualitative Research Methods: The Unstructured Interview. Canadian Journal of Dental Hygiene, 39(1), 14-22.

Cresswell, J. W. (2003). Qualitative, Quantitative. and Mixed Methods Approaches. In Research Design, Second Edition (pp. 3-26). https://doi.org/10.3109/ 08941939.2012 .723954

Creswell, J. W. (2007). Qualitative Inquiry And Research Design: 2, . (2007). Five qualitative approaches to inquiry. In Qualitative Inquiry and Research Design: Choosing Among Five Approaches (pp. 53-80).

Durkheim, E. (2001). The Elementary Form of The Religious Life: Sejarah Bentuk-bentuk Agama yang Paling Dasar. Translated by Inyiak Ridwan Muzir and M. Syukri. Jogjakarta: IRCiSoD.

Endraswara, S. (2010). Folklor Jawa: Bentuk, Macam, dan Nilainya. Jakarta: Penaku.

Hadisutrisno, B. (2009). Islam Kejawen. Yogjakarya: Eule Book.

Jensen, C. (2009). Poe(trees) of Place: Forest Poetics ini Lithuania and Tasmania. Journal of Ecocriticism, 1(2), 43-44.

Kesuma, D., Triatna, C., \& Permana, J. (2013). Pendidikan Karakter: Kajian Teori dan Praktik di Sekolah. Bandung: Remaja Rosdakarya.

Leoni, T. D., \& Indrayatti, W. (2017). Muatan Kearifan Lokal dalam Cerita Rakyat Kepulauan Riau. Jurnal Kiprah, 5(2), 61-80.

Listyarti, R. (2014). Pendidikan Karakter dalam Metode Aktif, Inovatif, dan Kreatif. Jakarta: Esensi.

Majeri Mangunjaya, F., \& Elizabeth McKay, J. (2012). Reviving an islamic approach for environmental conservation in Indonesia. Worldviews: Environment, Culture, Religion, 16(3), 286-305. https://doi. org/10.1163/15685357-01603006

Mangunjaya, F. M. (2011). Developing environmental awareness and conservation through Islamic teaching. Journal of Islamic Studies, 22, 36-49. https://doi. org/10.1093/jis/etq067

Mariati, S. (2013). Nilai-Nilai Kultural Magisme Tengger. Jurnal Agri. 3(1), 62-69 .

Merchant, C. (1990). Ecofeminism and Feminist Theory in lrene Diamond and Gloria Feman Orenstein (Eds.). Reweaving the World: the Emergence of Ecofeminism. SierraClub Books. San Francisco. CA.

Miles, M. A., Huberman, M. B. (1994). Miles and Huberman (1994)- Chapter 4.pdf. In Qualitative Data Analysis: An Expanded Sourcebook (pp. 50-72).

Mitchell, B. Setiawan, B., \& Rahmi, D.H. (2000). Pengelolaan Sumberdaya dan Lingkungan. Yogjakarta: Gajah Mada University Press. 
Negara, P. D. (2018). Budaya Malu Pada Masyarakat Tengger Dan Pengaruhnya Terhadap Budaya Hukum Penghindaran Konflik. Widya Yuridika, 1(2), 141152. https://doi.org/10.31328/wy.v1i2.743

Rijali, A. (2019). Analisis Data Kualitatif. Alhadharah: Jurnal Ilmu Dakwah, 17(33), 81-95. https://doi. org/10.18592/alhadharah.v17i33.2374

Riley, E. P. (2010). The importance of human-macaque folklore for conservation in Lore Lindu National Park, Sulawesi, Indonesia. Oryx, 44(2), 235-240. https://doi.org/10.1017/s0030605309990925

Saryono, D. (2008). Etika Jawa dalam Fiksi Indonesia: Representasi Nilai-Nilai Etis Jawa. Malang: Pustaka Kayutangan.

Semali, L M. \& Kincheloe, J. L.. (1999). What Is Indigenous Knowledge? Voices from The Academy. New York: Falmer Press.

Setiawan, I. (2008). Perempuan Di Balik Kabut Bromo: Membaca Peran Aktif Perempuan Tengger dalam Kehidupan Rumah Tangga dan Masyarakat. Humaniora, 20(2), 136-148. https://doi. org/10.22146/jh.v20i2.931

Smith-Hefner, N. J. (1990). The Litany of "The World's Beginning": A Hindu-Javanese Purification Text. Journal of Southeast Asian Studies, 21(2), 287-328. https://doi.org/10.1017/S0022463400003258

Spradley, J. P., \& McCurdy, D. W. (2012). Culture and ethnography. In Conformity and Conflict: Readings in Cultural Anthropology (pp. 1-5).

Sudikan, S. Y. (2015). Pendekatan Interdisipliner, Multidisipliner, Dan Transdisipliner Dalam Studi Sastra. Paramasastra, 2(1), 1-30. https://doi. org/10.26740/parama.v2i1.1496

Sukmawan, S. (2015). Sastra Lingkungan: Sastra Lisan Jawa dalam Perspektif Ekokritik Sastra. Malang: UB Press.
Sukmawan, S.-. (2018). Environmental Wisdom in Oral Literature of Arjuna Slopes People. Lingua Cultura, 12(1), 1-7. https://doi.org/10.21512/lc.v12i1.1459

Sukmawan, S., \& Febriani, R. (2018). PerempuanPerempuan Pemeluk Erat Adat: Studi Etnografi Perempuan Tengger. Linguista: Jurnal Ilmiah Bahasa, Sastra, Dan Pembelajarannya, 2(1), 1-7. https://doi.org/10.25273/linguista.v2i1.2682

Suseno, F. M. (1993). Etika Jawa: Sebuah Analisa Falsafi Tentang Kebijaksanaan Hidup Jawa. Jakarta: Gramedia Pustaka Utama.

Sutarto, A. (2003). Perempuan Tengger: Sosok yang Setia kepada Tradisi. Majalah Bende, Taman Budaya Provinsi Jawa Timur, tahun 2003.

Sutarto, A. (2008). Kamus Budaya dan Religi Tengger. Jember: Lemlit Universitas Jember.

Sutarto, A. (2017). Sastra Lisan Tengger Pilar Utama Pemertahanan Tradisi Tengger. ATAVISME, 12(1), 9-21 https://doi.org/10.24257/atavisme .v12i1 .153.9-21

Suyitno, I. (2008). Kosakata Lagu Daerah Banyuwangi: Kajian Etnolinguistik Etnik Using. Humaniora, 20(2), 179-190. https://doi.org/10.22146/jh.v20i2.935

Taniardi, M.A., P. N. (2018). Tradisi Megalitik Pada Ritual Kekerik Di Kalangan Masyarakat Tengger. Berkala Arkeologi, 33(2), 185 - 200. https://doi.org /10.30883/ jba.v33i2.27

Teorey, M. (2010). Ecological Discourse in Craig Child's The Secret Knowledge of Water. Journal of Ecocritism, 2(2), 1-13.

Triyoga, L. S. (2010). Merapi dan Orang Jawa: Persepsi dan Kepercayaannya. Jakarta: Grasindo.

Wilson, C. (2014). Unstructured Interview. In Interview Techniques for Ux Practitioners A UserCentered Design Method (pp. 43-62). https://doi. org/10.4135/9781412950589.n1059 